\section{A CASE OF RECOVERY AFTER A BROKEN NECK.}

By C. JORDISON, M.R.C.S.

ON Oct. 26th, 1881, Mr. C. S. P-, aged thirty.eight, when out cub-hunting, was riding at a canter over a fence under the arm of an oak tree, when his horse jumped much higber than he expecter, and the back of his neck came in violent contact with the concave surface of the branch. Mr. P - was leaning very forward over his horse's neck, and as the horse jumped almost perpendicularly upwards, the force of the blow was forwards and downwards. He was knocked off his horse, and lost consciousness for about two minutes. As soon as he could speak, he complained of intense pain up and down the neck and in his arms and legs. In less than ten minutes I was with him, when his first words were, "I am done for; my arms are paralysed, and the paralysis is extending over my body and into my legs." I noticed the respiration was normal. We carried him on a gate to the nearest farmhouse, where, after examination, I came to the conclusion that there were fractures of the laminæe of the fifth and sixth cervical vertebræ. At this time there was complete paralysis both of motion and sensation of the left upper extremity, and almost so, though to a less extent, of the right; impaired mobility of the left leg, the right being unaffected, and a sense of tingling and numbness over the whole body; there was perfect consciousness, and great pain in the neck and shoulders. He was laid upon a hard and perfectly flat mattress, with the head on a level with the shoulders, and this was kept immovable by sandbags. On the following day Mr. Bickersteth, of Liverprol, saw the patient with me. He concurred with my diagnosis, and we agreed that the paralysis was from injury to the roots of the fifth and sixth spinal nerves, and that the numbness of the body and partial paralysis of the left leg were due to extravasated blood outside the sheath of the cord. There was of course paralysis of the bladder, and for a few days slight difficulty in swallowing. The temperature never rose above $1014^{\circ}$. There was for a few days slight delirium and occasionally very great flushes, the whole head, neck, and face becoming of a deep-red colour, and this was always succeeded by great restlessness and irritability. By the third day he had entirely recovered motion in the left leg, and there was only slight tingling as far as the knee.

The treatment was absolute rest, but on the ninth day it was essentially necessary to change the bed linen, \&c.; and whilst this was being done crepitus was distinctly felt by the trained nurse, and beard by my assistant and myself. After this time the head was not moved again for many weeks. By the fourteenth day he had much greater power in the right arm, and he could just raise the left, but could hold nothing between the fingers; there were still numbness and tingling over nearly the whole body, also paralysis of bladder and sphincter ani. Perfect power of motion in both lege. Temperature $98 \cdot 2^{\circ}$, pulse 99 , respiration natural. There was a large amount of extravasated blood under the skin as far as could be seen down the neck, and extending from the spine to the left shouider-point After this time the paralysis of the arms became gradually worse, until at the end of the fourth week there was then complete loss of power of motion over the left arm and hand, accompanied with intense hyperæsthesia; almost complete paralysis of the right arm and hand, but less hyperæsthesia. On the left side there was complete atrophy of the hand, arm, and shoulder, the two pectorals being the first to waste away ; on the right side there was also some atrophy, but to a less extent.

This condition of utter helplessness continued without material change for about a week, when the power of emptying the bladder and of making an effort at defecation began very gradually to return, and slowly the power of moving the right arm was recovered so that by the eighth week he could hold an envelope or toothpick, but could not support a light book or even a newspaper. By the end of the eleventh week he could do as much with the left arm, the hyperæstbesia was gradually subsiding, but all the joints of the left arm and hand were very stiff and gave us much trouble. At this time he could slightly raise the head from the mattress and could rotate it freely. At the end of the thirteenth week I had my patient carried a distance of four miles on a stretcher to his own house, after which he began to make rapid strides towards recovery, and as the callus from around the fractured ends of the bones was absorbed, and the muscles again received their nerve supply, so he gradually recovered normal sensation in both arms and over the trunk and less rapidly the power of motion. At the end of the sixteenth week he was up and walking about ; there was decided prominence over the seat of the injury, and the head was unnaturally tilted forward, but only to a slight extent, so slight that it would not he noticed by anyone who had not known Mr. P- before the accident. The sensation and motion in the right arm were perfect, the sensation in the left nearly so, but there still existed great weakness, although there was no perceptible or measurable difference in the size of the two arms, the muscles having become developed more rapidly than they atrophied. At the end of the twenty-fifth week my patient was riding, driving, rowing, and swimming, having gone to Margate (by the advice of Mr. T. Bryant, who saw him about this time), and with the exception of a slight weak. ness in the left arm was perfectly well and strong.

Remarks. - I think undoubtedly we had here an injury to the spinal nerves by the broken fragments of the injured vertebræ, as the paralysis, numbress, \&c., were instan taneous. The paralysis of the left leg came on after a few minutes, and was probably due to blood extravasated ontside the sheath of the cord. I think the extreme paralysis about the fourth and fifth weeks was due to callus thrown out around the end of the broken fragments pressing upon the nerves as they emerge through their canals, and as this callus became absorbed so the power of motion, the sensation and the growth of the muscles were gradually recovered, and the now continuing weakness I attribute to there having been some slight laceration of the sheath of the nerve as it emerges from its canal, and the resulting thickening pressing upon and destroying some of the nerve fibres. I attribute the unusual and happy result primarily to there having been no interference with the respiratory tract, the injury having occurred just below the point of origin of the phrenic nerre, which possibly, in this case, did not receive a communicating branch from the fifth cervical; and, secondarily, to the great muecular development of my patient enabling him to with. stand the ill effects of long-continued pressure without the usual consequences, and to the fact that although the spine was broken the spinal cord was not injured. Malpas.

\section{NOTES ON A CASE OF PRURIGO FEROX; TREATMENT AND RECOVERY.}

By SURGEON SHIRLFY DEAKIN, F.R.C.S. EXG, OFFICIATIYG JUNIOR CIVIL SURGEON, ALLAHABAD.

As cases of Hebra's prurigo, fortunately for the unhappy patients, are rare in England, the following notes of a case successfully treated may be of interest. Dr. Tilbury For states in the last edition of his valuable work on "Skin Diseases," p. 156, that he had only met with one case. The case under observation presented little in common with cases of Scabies ferox, or Malabar itch, which are fully described in Drs. Fox and Farquhar's "Skin and other Diseases of India and Hot Climates," pp. 65 and 267.

Constable $\mathrm{N}-$, aged fifty-two, a Punjab Mussulman, was admitted to the Police Hospital on Oct. $26 \mathrm{th}, 187 \%$ suffering from severe itching of the skin of the whole surface of the body, excepting the palms of the hands and the soles of the feet; the back of the hands and the front of the feet, however, being especially troublesome.

Previous history. - Has suffered much from periodic (so. called "malarial") fever in past years. States that twenty. two years ago, at Peshawar, the eating of bhara, a kind of sheep, used to give him fever constantly. He denies a syphilitic history.

Present history. - Six months since he first noticed a severe itching between the shoulders, and presented himself at the hospital a month later on. Then he had much heat in the skin, and perspired freely during the night. When I saw him first the skin was but slightly thickened. Both lenses exhibited an advanced cataractous appearance, a con. dition very common at his age among natives of India. 
Bowels regular; tongue clean and firm; passes his urine slowly buc his febrile condition prohibited any attempt at exploring the urethra. He has a reducible right inguinal hernia, and there is a small swelling over the site of the left internal ring.

Piesent state.-The whole of the skin, excepting that over the scalp, chin, armpits, groins, and hernial sac, is much infiltrated and thickened. When uncovered the patient shivers greatly. He is terribly tormented with a constant itching, and scratches at his skiu in a must diutressing maner. His beard has fallen out, and the hair on his chest, which was abundant, has also disappeared, likewise the hair from the scalp; the moustache is firm. There were numerous slight abrasions all over the skin, caused by his nalls; these rendered it difficult to decide whether the patient suffered from phthiriasis or not; repeated examination, however, did not reveal any parasite.

Treatment was first commenced with three hot air baths with sulphur, quinine and iron being given internally, and weak carbolic oil, one in forty, freely applied over the skin. Subsequently he took five minims of solution of arsenic three times a day, and applied sulphur ointment, and then linseed o:l only. Potassium iodide in tifteen-grain doses twice a day, first alone, and afterwards with the addition of one-sixteenth of a grain of chloride of mercury, produced no effect; and on December 15 th, after six weeks' treatment, he was sent to his home in the Punjab on two months' sick leave no better. He was readmitted to hospital on February 20tb, 1879, on return from sick leave, no better for the change. His state is thus noted skin much thickened, as before described, and though he is fairly nourished he is much troubled by the itching. Ordered fifteen grains of powdered ergot twice a day. To have an alkaline bath : three ounces of bicarbonate of potash, two ounces of bicarbonate of soda, one ounce of borax, and one pound of bran, in thirty gallons of water. To use as a lotion: one drachm of hydrocyanic acid, two drachms of borax, one fluid ounce of solution of acetate of ammonia, in eight ounces of water. During his stay in hospital he had four biths as above, and tuok ergot for more than one month. He applied the lotion, using a bottle in eight days. Subsequently he took five miaims of solution of arsenic three times a day. Small lumps appeared on the skin somewhat resembling musquito bites, only often they were much larger, measuring an inch across. They were hard, raised, and redder in colour than the surr,unding skin. Each remained for half an hour or ss, aud then died away. When at his worst, some fifty or sixty such tubercles appeared daily.

Under treatment his condition greatly improved, the thickening of the skin disappeared to a large extent, the inner surfacts of the thighs remaining the worst. On the 21th of June he was convalescent and discharged to duty, doing his duty well until, on the 5th of October, 1879, he came up for examination previous to his discharge on pension. His state was then as follows:-Infiltration has disappeared from the skin of the face, and the face, consequently, looks much smaller; he has lost the peculiar smile, which recalled the risus sardonicus to one's mind, and which was due to exces-ive thickening in the region of the zygomatic and risorius muscles, and about the eyebrows. His beard has grown again thick and long; it is four inches in leagth, and the hair is quite black, as is also the hair on his chest, which has grown again luxuriantly. Before his illness the hair was nearly white. The bair on his head and in his moustache is now abundant, and of a dark-grey colour. He has not taken any medicine since he lett hospital Shortly after his discharge from hospital he came to the native doctor, $H$ ispital A ssistant Ram Lall Das, and asked him whether he had been given arsenic in hospital. His reason for doing so was that his friends hod attributed the chanue in the colour of his hair to the ad ministration of arsenic. It appear that the effect of arsenic in causing hair to become black is well known to natives. I have consulted Neale's Digest, Pinger, Fox, and,Bartholos, but cannot find any reference to this therapeut'cal effect of arsenic. There is still some slight itchiness of skin on the inner sides of the thighs, and slight thickening on the inner sides of the firearms. $\mathrm{He}$ is now free from the troublesnme perspiration. The gums are slightly spongy ; a scorbutic tendency, however, is generally prevalent among the pnorer natives, owing to the scarcity of vegetables and bigh price of food stuffs now current in this district. The man is well satisfied with his changed condition. When first treated, Dover's powder, belladonna, and ether were given to check the perspiration, but without effect. Ether, for suggesting the use of which in checking perspiration I am indebted to Dr. Balthazar Foster, has generally been in my hands most successful in doses of from ten to twenty minims of spirits of ether. It, however, is very volatile, and any mixture containing it should be dispensed daily and kept in a glass-stoppered bottle.

Allahabad.

\section{NOTES ON A CASE OF HAMATO-CHYLURIA.}

\section{BY JOHN D. HILLIS, F.R.C.S., F.R.M.S.}

ON March 26th last a sample of urine was forwarded to me for examination, together with the following history.

W. E. B - aged forty-two years, a coloured Creole of Demerara, stout and florid, has been for the past two years suffering from intermitttent hæmato-chyluria, previously to which he had always been a healthy man. The patient is not losing flesh, bat complains of an aching pain in his loins. Normal quantity of urine is secreted daily; skin acting well; pulse and temperature normal. On cooling, the urine is said to become like blancmange. The specimen of urine was of the colour of port-wine; reaction neutral ; specific gravity 1025, and contained a quantity of albumen. Examined microscopically, the field was covered with well-defined red blood-corpuscles, the urine also contained vesical mucas and some crystals of triple phosphate. It was late in the evening and only a cursory examination could be made. On March 30th I examined another specimen which contained a quantity of fatty granules, crystals of triple phosphate, a few chyle- but no blood-corpuscles; and there were a few cells of bladder epithelium, but no filariæ could be discovered after a very careful examination. On April 5th another specimen of W. E. B-'s urine was examined with $\frac{2}{3}$ and $\frac{1}{6}$ objectives. There were fewer red corpuseles, but an adult filaria sanguinis hominis was discovered on the second slide examined. I advised the patient being placed on decoction of rhizophora racemosa, which I have found most useful in cases of chylous urine. Under this treatment the patient considerably improved, the blood has entirely disappeared, and the urine does not coagulate on cooling. He states that "occasionally his back aches, and then his water becomes a little cloudy." I have had no further opportunity of examining either blood or urine, as he lives in a neighbouring county; but I can strongly recommend the mangrove bark in these cases.

British Guiana.

\section{A attlitror}

OF

\section{HOSPITAL PRACTICE, BRITISH AND FOREIGN.}

Nulla autem est alia pro certo noscendi via, nisi quamplurimas et morborum et dissectionum historias, tum aliorum tum proprias collectas habere, et inter se comparare.-MongAGN De Sed. et Caus. Morb., lib. iv. Procmium.

\section{GREAT NORTHERN H OSPITAL.} TWO CASES OF GUNSHOT WOUND; REMARKS.

(Under the care of Mr. SPENCER WATSON.)

For the following notes we are indebted to Mr. Wharry, house-surgeon.

A man having shot his wife, attempted his own life. On June 6 th Robert $\mathrm{C}-$, aged fifty-one, was admitted in the afternoon with four wounds on the right side of his scalp, all down to the bone. These had been caused by his discharging a revolver at himself. There was a good deal of hæmorrhage on admission, which was controlled by pressure. The wounds were enlarged, and search was made, but no bullets were discovered. Water-dressing was applied. The patient passed a restless night, and appeared next morning in a very depressed condition, continually lamenting over his condition, past and present. Pulse quiet; tem. 